Too Serious a Matter to Be Left to the Generals? Parliament and the Army in Wartime Portugal, 1914-18

Author(s): Filipe Ribeiro de Meneses

Source: Journal of Contemporary History, Vol. 33, No. 1 (Jan., 1998), pp. 85-96

Published by: Sage Publications, Ltd.

Stable URL: https://www.jstor.org/stable/260998

Accessed: 14-08-2019 10:37 UTC

JSTOR is a not-for-profit service that helps scholars, researchers, and students discover, use, and build upon a wide range of content in a trusted digital archive. We use information technology and tools to increase productivity and facilitate new forms of scholarship. For more information about JSTOR, please contact support@jstor.org.

Your use of the JSTOR archive indicates your acceptance of the Terms \& Conditions of Use, available at https://about.jstor.org/terms

Sage Publications, Ltd. is collaborating with JSTOR to digitize, preserve and extend access to Journal of Contemporary History 


\section{Too Serious a Matter to be Left to the Generals? Parliament and the Army in Wartime Portugal, 19/4-18}

The conflict between national assemblies and army high commands was a common feature of the political landscape of most belligerent countries during the first world war. There were, of course, variations to this conflict, as the power balance between parliaments, governments and military high commands differed from country to country. After having conceded extra powers to the executive branch and having exercised restraint over the military handling of the war, due to the general belief that the war would be brief, national assemblies began to reassert their authority. The reason was simple military stagnation and a succession of failed offensives led parliamentarians to attempt to regain control of the war effort, to reform it through criticism and new ideas. Clemenceau's witticism, 'War is too serious a business to be left to the Generals', captures this new mood perfectly.

1916, the year of Falkenhayn's great attrition battle at Verdun, saw the French parliament mounting its challenge to Joffre, responsible for the 1915 'nibbling' offensives and for the weakness of the Verdun sector. Joffre may have been protected by a government which associated its permanence in power with that of the army's commander-in-chief, but in the France of the Third Republic, where no real checks existed to the legislative branch's authority in peacetime, Joffre was involved in a race against time either to win the war or to be removed from command. Once the mood of the parliament had turned against the victor of the Marne, and the deputies and senators had overcome their initial reluctance to disturb the army during the war, a replacement for Joffre was quickly found. 1916 was also the year in which Germany declared war on Portugal, following the seizure of German merchant ships in Portuguese ports around the globe. Portugal's war effort was to be marked by great material and military difficulties, and by a difficult relationship between, on the one hand, the governments of António José d'Almeida (Evolutionist Party) and Afonso Costa (Democratic Party), and on the other the army sent by both men to Portugal's African colonies and to the centre of the European battlefield - Flanders. Although this relationship has been the object of recent study, ${ }^{1}$ its insertion into the overall domestic political balance of power during

1 José Medeiros Ferreira, O Comportamento Politico dos Militares (Lisbon 1992). 
the Great War has not been attempted, leaving unanswered questions pertaining to the role of the Portuguese parliament in wartime - was it informed of events at the front? And, if so, did it attempt to interfere with the army's conduct of the war?

The constitution of 1911 made the young Portuguese Republic a parliamentary régime, with a balance of power, on paper, similar to that of the French Third Republic. Restrictions on the franchise and the voluntary exclusion from politics of monarchists meant that both houses of parliament were controlled by the three descendants of the historic Portuguese Republican Party (Unionists, Evolutionists and Democrats), and especially by Afonso Costa's Democrats who, after the 1915 elections, enjoyed an absolute majority in both chambers. This control of the legislative body by a single and disciplined party represented the first major difference in the de facto balance of power in the Portuguese and French cases - for as long as the Portuguese government's leader continued to be the Democratic Party's leader, the executive would be in a position of strength vis-à-vis the legislative. The second major difference was the ambiguous loyalty of the army to the new régime (as opposed to the whole of the armed forces, the navy being distinctly republican). The army had fought on both the monarchist and the republican sides during the revolution which toppled the monarchy in October 1910, and no great purge of the officer corps followed, only 14 officers being dismissed, in addition to six deserters and 30 resignations. $^{2}$

The army's position in terms of loyalty to the régime was rendered more dubious after the outbreak of the Great War, when the officer corps provided the personnel and the support for the Pimenta de Castro dictatorship, which governed Portugal in the first half of 1915 , and which was overthrown by a violent revolution in which the army took no part. The army, as a result, added a degree of instability to the constitutional balance of power in Portugal. José Medeiros Ferreira points out that, when the Great War began, the army was not yet a unified political force. Only the most skilled of politicians could hope to lead such a potentially unreliable army into an enterprise of the Great War's magnitude and keep the various factions apart and, hence, committed to the war effort. One of the means employed by Afonso Costa, without doubt a skilled politician, was to allow for no criticism to be directed at the High Command, even from the parliament, and it is the employment of this perilous tactic, as well as its consequences, that this article addresses, through an examination of the secret sessions of the Chamber of Deputies, which took place in July 1917, and which have been surprisingly neglected by Portuguese historians.

In August and November 1914, as a result of both the European war and of Portugal's seemingly impending entry into that conflict, the powers of the executive, headed by the future President Bernardino Machado, were strengthened, a process which repeated itself in 1916, both immediately before

2 Ibid., 43. 
and after the German declaration of war. Such actions, however, did not mean that the Chamber of Deputies had become completely subservient to the government. At the end of 1916 concerted actions by the more conservative Unionist Party and breakaway Evolutionist deputies, who together formed the 'Parliamentary Bloc', severely shook the Sacred Union government led by António José d'Almeida (composed of Evolutionist and Democratic ministers), ${ }^{3}$ and in April 1917 that same Sacred Union government was toppled on the grounds of parliamentary prestige and prerogatives by Democratic backbenchers and the Bloc. ${ }^{4}$

Members of Parliament of all belligerent countries fought in the first world war, and Portugal was no exception. ${ }^{5}$ Through these men and other, private contacts, the rest of Portugal's parliamentarians were able to create a more detailed idea of the nature and the problems of the country's war effort than the rest of the population. Whether simply out of concern for the men of the expeditionary forces, or because military difficulties provided an excellent weapon against the huge governmental majority, opposition deputies, from an early date, began to use parliamentary debates on the course of the war to embarrass the government. The German bombardment of Funchal (December 1916) provided such an opportunity, Hermano de Medeiros, a deputy from the Azores, pointing out that

Any apprehensions that may exist should not be confined to Funchal, they should be extended to the Azores. I am convinced at this moment that the islands have no means of defence against a possible attack, the same being true of Madeira. ${ }^{\circ}$

The same deputy would speak out again in July 1917 when Ponta Delgada, in the Azores, fell victim to fire from a German U-Boat, and called for a secret session 'so that we may tell you [the government] things that cannot be told in a public session'?

3 Because of laws designed to delay the trial of those involved in an attempted coup - laws which were deemed to be retroactive and as such unconstitutional.

4 This time the conflict arose because of the institutional strengthening of the newly-created National Economic Council, seen by the backbenchers as an affront to parliament. The government's defeat occurred during Afonso Costa's absence from the country, and the Democratic deputies who brought the government down claimed that Costa would never have approved of the government's action.

5 The polemic which, in 1917, surrounded Brito Camacho's postponement (and later abandonment) of his military obligations as a doctor in the military reserve, and the acceptance of his decision by the rest of the Chamber of Deputies, shows that it was possible for a deputy who invoked his rights as a representative of the popular will to forego serving at the front. Brito Camacho's case is doubly interesting both because it reasserted the primacy of the rights of the deputy and because the leader of the opposition was establishing a precedent. Jaime Cortesão, at the time a Democratic deputy, attacking Brito Camacho, stated that 'The fundamental code [the constitution] cannot be omniscient. Some rights are degrading and the right to remain in the country, to not go to war, to not accept one's military duty, is a right that humiliates this Chamber.' The whole debate can be found in the Diário da Câmara dos Deputados, 13.2.1917.

6 Ibid., 4.12.1916.

7 Ibid., 4.7.1917. 
Campaigns in Africa, notably the 1916 expedition to Mozambique, were also an object of criticism. ${ }^{8}$ After the siege and defeat of Newala, in German East Africa, announced by the Prime Minister and Minister for the Colonies on 5 December, José Barbosa, presenting a negative overview of the government's achievements, asked: '[Did the government] increase our colonial prestige? No. [Cheers] Ah! Mr President, it is better not to talk about that matter .... Alfredo de Magalhães, bitter after his arrest by military authorities during the December 1916 coup attempt, attacked the government on all fronts, including the African campaign. Boer troops were carrying out the tasks which should have been dealt with by the Portuguese, a fact which, in the deputy's opinion, would have serious diplomatic repercussions. Magalhães asked, 'Why did we invade German colonies without the necessary numbers?', and stressed that those responsible for the defeat should be identified. Finally, Magalhães asked why the reports written by the commanders of earlier African expeditions - Pereira d'Eça and Alves Roçadas - had not yet been published by the government, adding: 'If [parliament] were to live up to its noble function, it would demand a complete account of all the government's actions." Tamagnini Barbosa, another member of the parliamentary bloc, and a frequent speaker on African topics, denounced the government on 6 June 1917 for being too harsh in charging the 'hut tax' in Angola, which had led to a recent wave of revolt, resulting in the death of 87 Portuguese. The following day, Tamagnini Barbosa claimed in the Chamber of Deputies that

It seems that the State has not benefited in any way from the recent expeditions sent [to Angola], because the pacification of Angola is on exactly the same footing that it was years ago, despite the enormous sacrifices that the State has had to make in lives, material and money. ${ }^{10}$

Parliamentary opposition to the government on the subject of Portugal's war effort reached a peak in the summer of 1917, when the Minister for War, Norton de Matos, announced the results of talks in London regarding the size of Portugal's commitment to the European battlefield - an army corps of 55,000 men, with monthly shipments of 4,000 men to cover losses, and an independent heavy artillery force $(1,500$ men) to serve with the French army. The Minister added that 30-35,000 men had been sent to Africa (for a total of 45,000 soldiers, including African troops, in both Angola and Mozambique),

8 Incursions were launched early in 1914 from German East Africa and German South-west Africa into Portuguese territory, Germany's hopes of expansion into Mozambique and Angola being well documented. Fighting took place in both Portuguese colonies, and a succession of expeditions was sent from Portugal to her African colonies. In 1916 the government urged General Gil, the commander of the troops in Mozambique, to invade East Africa in order to capture part of its territory before the colony fell to the British and Belgian troops operating in the area, and the invasion took place with, as we shall see, disastrous results. One of Sidónio Pais's first actions was to reveal Gil's report to the press; its conclusions can be read in any leading Portuguese daily after 22.12.1917.

9 Diário da Câmara dos Deputados, 2.2.1917.

10 Ibid., 7.6.1917. 
and that a reserve of 40,000 men would be needed in Portugal itself. The opposition leader, Brito Camacho, called for secret sessions and, once these had been agreed to, claimed, while still in a public session, that the government had not been given the power to conclude military conventions, and that troops were being sent to Africa 'like herds to the slaughter' - an allegation that some men had been sent to Africa without having received even basic military training. ${ }^{11}$

The secret sessions of parliament lasted from 11 to 26 July, a troubled time in a Lisbon hit first by a construction workers' strike and then by martial law in response to the strike. The Bloc left the sessions on 25 July, however, leaving the lone Socialist deputy as an opposition, effectively bringing the sessions to an end. The range of criticism to which the government was subjected over two weeks was enormous but, because the discipline of the Democratic Party and its allies - the mainstream Evolutionists - held firm, the Parliamentary Bloc found itself unable to force the government into any concessions or even into a full disclosure of all information pertaining to Portugal's involvement in the war, be it on a military plane or a political one. The Bloc's objections were built around the idea of parliamentary prestige, a prestige it saw as being tarnished by the ignorance in which the Chamber of Deputies had been kept since, essentially, 1914. Starved of information, and having relinquished many parliamentary prerogatives to the executive at the start of the European war, the opposition, faced by what it saw as the country's deepening crisis and the poor handling of military affairs, now sought to re-establish parliament's powers through a series of investigations into the treaties and conventions which Portugal might have signed since 1914, and into the actual military campaigns. The government, for its part, refused, claiming that it would be folly to allow such investigations to take place while Portugal's armies were on the field of battle, and before the final peace negotiations. We shall concentrate on the military criticisms made by the parliamentary opposition, and on the government's response to those criticisms. ${ }^{12}$

The Bloc's criticisms of Portugal's ongoing military effort singled out the lack of adequate preparation which had so far characterized that effort, and identified political interference as the main reason for the many deficiencies which had resulted in terrible suffering and unnecessary loss of life among the fighting men in Africa and in Europe, not to mention massive expense. According to opposition deputies, a political decision had been made as a result of which soldiers in Africa would be sacrificed, in terms of equipment, so that the soldiers in the more visible battlefields of France might enjoy

11 Ibid., 6.7.1917.

12 This is not to say that the attempt to re-establish parliament's rights in the diplomatic sphere is without interest, or that it was a secondary matter, as the words of Moura Pinto make clear: 'Today this convention with France, tomorrow one with Russia, the following week another one with Serbia. All of this at a time when the country is already making too large a sacrifice, as is said and felt everywhere. It is very easy to negotiate with the blood of others, and then, with a recourse to easy rhetoric, to claim that blood as one's own! Only parliament has the right to negotiate when it comes to such sacred raw material. Enough excesses. The Executive in its place.' 
parity with the Allies. This decision, dubious to begin with, had been rendered ridiculous following the Allies' insistence on standardization in the trenches, which had led to the stockpiling in France of Portugal's modern military equipment, badly needed in Africa, where soldiers had to contend with diverse and obsolete artillery and infantry weapons. Vasconcellos e Sá, an Evolutionist member of the Bloc, forwarded a motion attributing responsibility for the military 'disasters' at Naulila, Rovuma and Newala to the expeditions' faulty organization in personnel and material, and to the government's unwillingness to send reinforcements while attempting to run the campaigns, by cable, from Lisbon. ${ }^{13}$ Tamagnini Barbosa described the medical component of the Portuguese Expeditionary Corps in France (CEP) as wholly inadequate, and pointed out that men unfit for military duty were being sent to the front, including consumptives. He added that administrative tasks in the field armies should be alternated with trench duty, to ensure the disappearance of the 'shirkers' - men entrusted with duties at the rear bases and depots, with the handling of statistics and with translation work. ${ }^{14}$ The same deputy also highlighted the terrible shortages of adequate medical material sent to Mozambique for the campaign against the Germans in East Africa, and the poor use of what resources were available ${ }^{15}-$ an accusation seconded by Tomás Rosa, an officer, and the sole Democratic deputy to speak out against the handling of the war. ${ }^{16}$

More seriously still, Tamagnini Barbosa delivered a stinging attack on General Gil, ${ }^{17}$ the commander of the unfortunate 1916 Mozambique expedition, claiming that the General had remained 60 leagues behind the fighting, playing bridge with his entourage and displaying total lack of interest in the plight of the men assigned to him, that he had neglected to secure positions between the rear bases and the advancing troops, leaving both exposed, and that he had failed to ensure that the advancing troops carried out an effective reconnaissance, which led them into the German trap at Newala. ${ }^{18}$ Tamagnini Barbosa did not hesitate to qualify Gil's performance as 'disastrous for the country and shameful for the Portuguese army'. Casimiro de Sá spoke, among other topics, of shortages of food for the soldiers of the CEP at a time when other Allied soldiers were adequately fed. ${ }^{19}$

13 Transcripts of the Secret Sessions of the Chamber of Deputies, 41.

14 An obvious reference to Sebastião Costa, son of the Prime Minister and a translator in the CEP. Transcripts, $11 \mathrm{ff}$.

15 Transcripts, $45 \mathrm{ff}$.

16 According to Tomás Rosa, a German emissary advised the Portuguese troops crossing the Rovuma river into German territory to move their first aid station, located 30 metres away from an artillery battery supporting the river crossing. Transcripts, 47.

17 Tamagnini Barbosa accused the government of choosing Gil because of his Republican leanings, despite the fact that he had no prior African experience - a charge which the government did not deny.

18 According to Tamagnini Barbosa, apart from heavy casualties, including POWs, the Newala defeat cost Portugal 1 radio post, 4 artillery pieces, over 500 shells, 8 machine-guns, 1,500 rifles, 60,000 rounds of ammunition, 5 lorries and 100 ammunition carts.

19 Transcripts, 24. 
The most damaging accusation against the army came from the alreadymentioned Tomás Rosa, who read out to the Chamber a series of sworn statements made by officers and sergeants who had taken part in the 1915 expedition to Angola. ${ }^{20}$ According to these statements, General Pereira d'Eça, the commander of the expedition, had condoned, and possibly ordered, brutal reprisals against the tribes which, aided by Germans in South West Africa, had revolted against the Portuguese in 1914. This rebellion had been crushed only after a long campaign, marked by large set-piece battles such as that of Mongua, during which 2,000 Portuguese soldiers had been surrounded by an estimated 12,000 tribesmen, 5,000 of whom had rifles. ${ }^{21}$ According to the statements read out by Tomás Rosa, large-scale hangings and other atrocities had been carried out in order to punish the rebellious tribes, which had seriously hampered the Portuguese army in its retreat after the 1914 defeat at Naulila. Hundreds of men were allegedly hanged, in the full knowledge of officers, and surrendering families were split up, men being hanged and women and children being forced to march in the direction of rival tribes' territory - essentially a slower death sentence. One surrendering man, having been identified as a notable of his tribe, was crucified for a day before he, too, was hanged. A letter, written by a soldier and read out by Tomás Rosa, stated that 'We have orders to kill all the natives from the age of 10 upwards'. ${ }^{22}$

How did the government react to this barrage of highly damaging criticism? Essentially by accusing the opposition of lack of patriotism in its airing of grievances, and by promising full enquiries once the war had ended and the peace settlement had been finalized. Brito Camacho was the main target of the government's broadside. Afonso Costa accused him of failing to see the moral advantages of Portugal's participation in the war, of being petty and inferior in his treatment of the war as a business - weighing up Portugal's help to Britain and France ('glorious nations') against gains to be made from that help.

20 These statements are included in the transcripts as an appendix, and are typed, as opposed to the debates themselves.

21 João Ferreira do Amaral, A Mentira de Flandres e. . o Medo (Lisbon 1922), $141 \mathrm{ff}$.

22 What follows is the translation of one of the statements, made by a certain Francisco Filipe de Sousa: 'I hereby declare that, having served in the expedition to the South of Angola in the year 1915 , I was told of deeds so inhuman that I will refrain from reproducing them here, as they have already been reproduced in other statements of which I know and which I confirm.

While crossing the zone of operations, as head of supplies and uniforms, I saw many black men and women hanging from trees, and, from one tree in Humbe, a veritable bunch of humans. They called that tree the "fatal baobab". I saw many blacks being hung on that tree and I was told that the hangings were always preceded by an order from above. The blacks were buried before being dead and one black hangman, having been asked by me why this was being done, replied that he had orders from the "manéputo", their name for the General. The blacks were hanged with barbed wire, and although I cannot give a precise figure for those who were hanged, I nevertheless know that it was high .... I was told by the military commander of Humbe, Infantry Captain J.V.C., that upon taking command of that locality he had been forced to carry out a large clean-up operation, for the number of blacks who had been killed by hanging was so high that he feared an outbreak of disease ... . I have knowledge of orders having been given for the transformation of bullets into "dum-dum" bullets, designed to cause great destruction in the human body, so that the General's name might not be forgotten among the blacks for at least five years after our victory.' 
Brito Camacho is an unfortunate man. He is driven by fate to do harm. I will not ask him to change his ways. Let him go on. One day he will be struck by remorse. ... Having had the chance to render services to his country, and to contribute to the resurgence of his Fatherland, he rendered no such service and only harmed the Republic. ${ }^{23}$

Personal remarks aside, the government was content to allow its majority to stifle any opposition moves. As Afonso Costa put it, 'The government has received from the parliament all the necessary authorizations to wage war and thus carries out all actions that might be necessary and convenient towards that end'. ${ }^{24}$ The Prime Minister, moreover, on various occasions challenged the opposition to a vote of confidence. However, while delaying tactics worked in relation to parliamentary inquests into the signing of conventions, into the quality of the medical service being provided for the men at the various fronts, and into the appointment of General Gil as the commander of the 1916 expedition, the question of the atrocities in Angola could not be dealt with in the same manner - not only because of the repugnant nature of the alleged deeds, but also, and perhaps more importantly, because General Pereira d'Eça, following his energetic pacification of Southern Angola, had been given the coveted post of Military Governor of Lisbon.

As we have already seen, Lisbon, during the secret sessions, was in a state of martial law, constitutional guarantees thus being suspended and power residing in the hands of the army. An absurd situation had been created while the Portuguese capital was run by a General, the question of whether or not that same General was a war criminal was being discussed in the Portuguese legislature. ${ }^{25}$ Brito Camacho, while pointing out that 'the so-called inferior races are merely backward - one cannot civilize them through their elimination', stated that under no circumstances should Pereira d'Eça remain at his post. Moura Pinto seconded his leader's demands: 'I believe it to be a rudimentary principle of military justice that a unit commander should answer for all the errors, mistakes or crimes which take place under his command, until he uncovers the names of those responsible. ${ }^{26}$ Pressing home his attack, Moura Pinto turned his fire against the democratic government:

It is absurd for the Minister of War to want to maintain in a very sensitive post - as is that of supreme governor of Lisbon during a suspension of constitutional guarantees - a General

\section{Transcripts, 17.}

24 Deputy Francisco Trancoso, a Democrat, put forward the following motion: 'The Chamber, believing that the government has proceeded within the sphere of the parliamentary authorizations in all that refers to the state of war with Germany, and that its action has always been oriented in harmony with the high interests of the Fatherland and the Republic, as well as constitutional precepts, moves on to the daily order of business.' Transcripts, 21.

25 Independent republican newspapers, not to mention the working-class and monarchist press, unequivocally blamed the authorities for the violence which followed the construction workers' peaceful demonstration through the streets of Lisbon; O Século put casualties at six killed and 28 wounded, in what it called 'a real battle', during which the Republican National Guard had 'lost its head'. O Século, 14.7.1917.

26 Transcripts, 55. 
against whom documents, so far uncontradicted, were produced in this parliament, which showed that the column under his command committed savage atrocities, possibly in accordance with his orders, atrocities which no state of war can justify, barbarous acts so stupidly cruel that only with amazement, indignation and repulsion was the Chamber able to hear them. ${ }^{27}$

Moura Pinto, finally, accused the government, which seemed so reluctant to part company with Pereira d'Eça, of knowing about his actions in Africa and recognizing in them the solution to the problem of public order in the capital.

Afonso Costa responded to these accusations swiftly, affirming his, and the government's, full support for the embattled General. Once again the Prime Minister made the issue one of confidence in the government, and once again his party and the majority of Evolutionists maintained their discipline. Moreover, Afonso Costa said that no country at war would be so foolish as to make public such potentially harmful information and, momentarily forgetting about Portugal's civilizing mission, that Africans equated humanitarian concerns with weakness. In attacking General Pereira d'Eça, 'who is a man of honour', and whose orders in his present capacity had all been 'aimed at defending our institutions, as well as order and public safety', the opposition, according to the Prime Minister, was attempting no more than the overthrow of the cabinet, which revealed a lack of political wisdom, 'for, in truth, they are not in a position to replace it'. ${ }^{28}$

The Bloc's solution to the problem caused by the atrocities committed by the Pereira d'Eça column was the reassertion of parliament's authority over the army, in the shape of a parliamentary enquiry into the Angolan campaign. The government's supporters (through back-bencher António da Fonseca, a Democrat) replied that such an enquiry should be left to the Ministry of War - a view rejected by Tamagnini Barbosa, who considered it to be 'an abdication of competences' on the part of parliament, one which would endanger its institutional prestige - as well as being a formula through which the truth would never be arrived at. ${ }^{29}$ Moura Pinto's motion, not admitted for a vote by the majority, called for a parliamentary enquiry into Pereira d'Eça's campaign and the immediate lifting of the state of siege in Lisbon. Norton de Matos replied that there was no question of offence to parliament, but that in the difficult situation facing Portugal, only the Ministries of War and the Colonies could carry out enquiries with the necessary secrecy. The government's victory was never in doubt and, on 25 July, the Parliamentary Bloc abandoned the secret sessions. In an interview with O Século, Brito Camacho made it clear that he no longer expected anything from the present government, and that he would henceforth attempt to organize all the social forces that no longer felt themselves to be represented by parliament - 'The country does not want a sectarian Republic, a Republic of factions, a Republic in which all crimes go unpunished and where there are no guarantees to safeguard all legitimate

27 Ibid.

28 Transcripts, 56.

29 Transcripts, 57. 
interests.' Moreover, the Unionist leader hinted at what had happened in the secret session and the reasons for the Bloc's withdrawal. ${ }^{30}$

The government's intransigence on the question of the proposed parliamentary enquiry into the Angolan campaign of 1915 poses a wide array of problems. Would Portugal's claims on its African colonies, and its intended civilizing mission, be tarnished by the revelations of the atrocities committed by its army in 1915? Would the country's wartime morale suffer as a result? And, most importantly, how would the army react to such an enquiry? The answer to the first two questions is probably no (although their exploration falls outside the scope of this article). ${ }^{31}$ General Pereira d'Eça was an officer of great prestige, as the number of subsequent hagiographies makes clear; one possible explanation for Afonso Costa's refusal to move against him was that such an action might lead the unreliable army to unite around the embattled General - passing the blame for the disasters in Africa to the government and, if necessary, removing the government from power, with disastrous consequences for Portugal's international standing. This explanation would tie in easily with the interventionists' hopes for the war, seen as a process through which two important aims could be achieved rapidly: the mobilization of the Portuguese population around the new régime, through an appeal to that population's presumed patriotism which would split monarchist and Catholic opinion, and the acquisition of a new international prestige, due to Portugal's sacrifice in the war, which would render Portugal immune from any future territorial challenges, from either Spain or rival colonial powers.

The final act of the conflict between parliament and the army occurred in the last days before Sidónio Pais's coup, which was to transform Portugal's participation in the war, ${ }^{32}$ and it was organized by the deputies who had been in the front line and who, as a result, had direct knowledge of the Portuguese Expeditionary Corps' shortcomings. Jaime Cortesão, the author of one of the most important wartime diaries in Portugal, referred in that work to a meeting of the Democratic Party's deputies at the front, in which those deputies had

30 'Look at what happened in Africa. We began to send military expeditions as soon as the war broke out in Europe and, having sacrificed many men and enormous sums - millions of Escudos - we succeeded in causing revolts in Angola and Mozambique, where the Germans are still occupying our territory. We suffered a disaster in Naulila, we suffered a disaster on the Rovuma, and we suffered a disaster in Newala, and on none of these subjects has the country been given any explanations by the government.' O Século, 2.8.1917.

31 Thomas Pakenham's The Scramble for Africa (London 1991) illustrates the ferocity with which African rebellions were regularly suppressed; the revolt of the tribes in Southern Angola in 1914 was, moreover, aided by the Germans, making the retaliatory atrocities more palatable to the Portuguese and Allied opinion - Germany could be portrayed as being ultimately responsible for all that had happened. Moreover, colonial campaigns, notably in Mozambique (curiously ignored by Pakenham), had provided the Portuguese army with a series of successes, and domestic approval, at the end of the nineteenth century.

32 Under the Presidency of Sidónio Pais, who had been the Portuguese Minister in Berlin until the German declaration of war in 1916, no reinforcements were sent to the CEP, whose first-line strength was quickly reduced through casualties and illness to that of a single division, incorporated in a British Army Corps, and finally eliminated in the battle of 9.4.1918. 
decided to attend the next session of parliament (which was to re-open in December 1917) in order to correct the 'serious defects and errors' ${ }^{33}$ in the CEP's organization, and to replace the government. According to A Capital, a republican, but now anti-Afonso Costa Lisbon daily, a race now developed between the returning deputies (Sá Cardoso, Alvaro Pope, Vitorino Godinho, and Joaquim Ribeiro, among others) and Afonso Costa, who had been in London, not only to return physically to Lisbon, but also to harness support among the undecided Democratic deputies. ${ }^{34}$ The prestige attached by these undecided Democrats to the fighting deputies was sufficiently great to pose a serious threat to the otherwise stable (in parliamentary terms) government. The fourth of December was a day of rumours and counter-rumours, and $A$ Capital printed all of them - that a minority Evolutionist government was in the making, that Afonso Costa would fight to defend his government, that he would present parliament with a reshuffle once he had arrived and, finally, that he would resign. With the public's attention focused on the ministerial crisis, Sidónio Pais finalized his preparations for his assault on power, ${ }^{35}$ intelligently carried out while Afonso Costa had still not reached Lisbon.

The failure of the secret sessions of parliament to allow the legislative branch to call the army to account for all the decisions which had been made since the beginning of Portugal's involvement in the war, many of which appeared, to some deputies at least, to have been harmful to Portugal's immediate and long-term interests, resulted both from the size and discipline of the government's huge majority in the Chamber of Deputies and, more importantly, from the government's unwillingness to allow direct challenges to be mounted to the army - an unwillingness more than demonstrated by the refusal to act against Pereira d'Eça's continuing military rule over Lisbon. In order to understand this unwillingness, stronger light has to be shed on the relationship between the government and the army which it nominally controlled but which, having been sent into a war that many of its leaders saw as being irrelevant to Portugal's interests (not counting, of course, the colonies), had been showing grave signs of discontent. ${ }^{36}$ The Democrats, who believed that through participation in the war Portugal and its new régime would acquire a more positive, international image - readily contrastable with that of reactionary and neutral Spain - were willing to sacrifice the notion of parliamentary prestige in order to allow the army to carry out its task without parliamentary interference. The direct questioning by parliament, of the authority of a prestigious General such as Pereira d'Eça, might just provoke

33 Jaime Cortesão, Memórias da Grande Guerra (Lisbon 1919), 105.

34 Hence the lack of a quorum on 3 December was described by A Capital as a manoeuvre by Afonso Costa's supporters to buy time until their leader's return.

35 Some of the military units which participated in the coup had been earmarked for deployment to Flanders.

36 These signs of tension between the army and the government are readily found in the Documents of the Ministry of the Interior (in Lisbon's National Archives) and in the documents of the Ministry of War's Information Service - available for consultation at the Army's Historical Archive in Lisbon. 
the army into seizing power and withdrawing from the war effort, or drastically restructuring that war effort, as had happened in 1915 under General Pimenta de Castro's dictatorship (which had enjoyed considerable support among officers), as might have happened through the December 1916 coup led by the Revolutionary hero, Machado Santos, and was to happen, finally, in December 1917, under the leadership of Sidónio Pais.

Filipe Ribeiro de Meneses received his doctorate from Trinity College Dublin in 1996 for his thesis The Failure of the Portuguese First Republic: An Analysis of Wartime Political Mobilization. He was appointed Lecturer in Spanish History at St Patrick's College, Maynooth in 1997, and is currently editing a collection of documents concerning Portugal's involvement in the first world war. 